\title{
Standing on one shoulder
}

Citation for published version (APA):

Duyx, B. (2019). Standing on one shoulder: citation bias in the epidemiological literature. [Doctoral Thesis, Maastricht University]. ProefschriftMaken Maastricht. https://doi.org/10.26481/dis.20190417bd

Document status and date:

Published: 01/01/2019

DOI:

10.26481/dis.20190417bd

Document Version:

Publisher's PDF, also known as Version of record

\section{Please check the document version of this publication:}

- A submitted manuscript is the version of the article upon submission and before peer-review. There can be important differences between the submitted version and the official published version of record.

People interested in the research are advised to contact the author for the final version of the publication, or visit the DOI to the publisher's website.

- The final author version and the galley proof are versions of the publication after peer review.

- The final published version features the final layout of the paper including the volume, issue and page numbers.

Link to publication

\footnotetext{
General rights rights.

- You may freely distribute the URL identifying the publication in the public portal. please follow below link for the End User Agreement:

www.umlib.nl/taverne-license

Take down policy

If you believe that this document breaches copyright please contact us at:

repository@maastrichtuniversity.nl

providing details and we will investigate your claim.
}

Copyright and moral rights for the publications made accessible in the public portal are retained by the authors and/or other copyright owners and it is a condition of accessing publications that users recognise and abide by the legal requirements associated with these

- Users may download and print one copy of any publication from the public portal for the purpose of private study or research.

- You may not further distribute the material or use it for any profit-making activity or commercial gain

If the publication is distributed under the terms of Article $25 \mathrm{fa}$ of the Dutch Copyright Act, indicated by the "Taverne" license above, 


\section{Summary}

The general purpose of scientific research is to develop and improve knowledge. To achieve this, it is essential to build upon and take into account previous research. References in the reference lists or research articles indicate which previous research has been taken into account. These references should be representative of the published literature. Otherwise knowledge development might be biased, and research lines could be unwarranted and wasteful. When references are not representative, this is called selective citation. When selective citation is based on study outcome, this is called citation bias.

Chapter 1 starts with some philosophy of science. Karl Popper's principle of falsification is explained and applied to the field of epidemiology. This principle states that science can only progress if non-supportive, or falsifying results, are taken into account and even actively searched for. Some epidemiologists criticised his philosophy, stating that it is not relevant for epidemiology. Much of this criticism seems to be flawed or outdated. For epidemiological hypotheses to grow and corroborate, it is essential that they can be falsified, and in order to be falsified, negative results have to be taken into account. Without the possibility of negative results, positive results would be rendered meaningless.

This chapter ends with an overview of several dissemination biases that favour supportive results over non-supportive ones. It concludes that the existence of these biases harms the growth of scientific knowledge within epidemiology. Much research has already been devoted to outcome reporting bias and publication bias, and good solutions have been proposed. This is not yet the case for citation bias.

Chapter 2 presents a systematic review and meta-analysis on citation bias. The systematic review reveals that several different research methods were used to assess citation bias. The methods varied on how the network was defined ('article selection'), how the study outcome was measured, and which statistical analysis was applied. Regardless of these methodological differences, the review concludes that supportive publications are cited about twice as often as non-supportive ones, showing evidence of a modest citation bias across research fields. This bias is independent of the article selection method, but it seems stronger if study outcome is based on the authors' conclusion rather than on the actual results.

The dissertation then continues with three citation analyses, each one on a different field of epidemiological research. For these citation analyses we adopted a 
claim-specific article selection approach. In this approach, all relevant publications on one pre-specified hypothesis are included in the citation network. Because all publications within such network relate to the same hypothesis, one would expect that supportive and non-supportive publications would receive a similar amount of attention as expressed by the number of citations they receive.

Our first citation analysis, in Chapter 3, examines the research on the association between swimming in chlorinated water and the development of asthma in children. The small size of the network prevents us from drawing strong conclusions, but it seems safe to say that there was clear evidence for selective citation. On the other hand, the evidence for citation bias was weak. Interestingly, we observed that this research field mainly consisted of two groups of researchers. One of these groups tended to produce supportive results, whereas the other group was more critical towards the hypothesis under investigation.

Chapter 4 presents our study on the hygiene hypothesis. This hypothesis was coined by David Strachan and inspired a lot of research up until today. The original hypothesis states that the lack of infections in childhood increases the risk of rhinitis later in life. Some of its predictions were falsified, and this led to the improvement of the hygiene hypothesis and to the advancement of our understanding. Curiously though, citation bias seemed quite strong in this research area.

Finally, in Chapter 5, the research field on the association between exposure to diesel exhaust and lung cancer is explored. It shows a) that study outcome seems unrelated to the likelihood of citation, b) that higher quality publications are cited more often, and, finally, and c) that publications funded by the transport industry are much more critical about this association than publications funded by non-profit organisations.

Chapter 6 introduces a new concept: abstract reporting bias. Abstract reporting bias is the phenomenon that publications that investigate a multitude of associations, only report the supportive ones in their abstract. As search engines, such as Web of Science and PubMed, limit their search to the title, abstract and keywords fields of a publication, this means that non-supportive results are more difficult to identify. Consequently, systematic reviews might be biased, and pooled estimates in meta-analyses might overestimate the real effect.

Additionally, this chapter presents a method to identify abstract reporting bias and it applies this method on a research field concerning the association between diesel exhaust and bladder cancer. It shows that in this field, about $20 \%$ of all the published evidence is missed because of the bias in abstract reporting, and that this leads to a (non-significant) seven percentage point overestimation of the pooled estimate. 
Chapter 7, finally, discusses all the citation analyses from the Sound Science project. This includes three analyses that have a similar methodology but are not included in this thesis. General patterns over all six research fields are investigated. Citation bias, overall, was quite modest. Sample size, journal impact factor, authority and self-citation seem to be stronger determinants of citation than study outcome is.

An interesting, yet explorative, finding is that citation bias seems strongest in the case of supportive publications citing other supportive publications, and that nonsupportive publications do not seem to have a preference to cite either supportive or non-supportive publications. On the other hand, we could not replicate our earlier finding that citation bias is strongest if it is based on the authors' conclusion rather than on the underlying data. 



\section{Nederlandse samenvatting}

Het doel van wetenschappelijk onderzoek is het ontwikkelen en verbeteren van onze kennis. Om dit voor elkaar te krijgen is het van belang om verder te bouwen op eerder onderzoek. Referenties in de referentielijsten van onderzoeksartikelen geven aan op welk onderzoek wordt voortgebouwd. Deze referenties zouden representatief moeten zijn van de gepubliceerde literatuur op het betreffende onderwerp. Anders kan de kennisontwikkeling vertekend raken, of wordt er zonder goede aanleiding onderzoek opgezet dat nergens toe leidt. Als referenties niet representatief zijn, dan noemen we dit selectieve citatie. Als deze selectieve citatie van eerdere literatuur wordt gebaseerd op studie-uitkomst, dan noemen we dit citatiebias.

Hoofdstuk 1 begint met wetenschapsfilosofie. Karl Poppers falsificatieprincipe wordt geïntroduceerd en toegepast op epidemiologisch onderzoek. Dit principe stelt dat de wetenschap alleen vooruitgang kan boeken als negatieve, of falsificerende, onderzoeksresultaten worden meegewogen, en het liefst zelfs dat hier actief naar wordt gezocht. Sommige epidemiologen bekritiseren zijn filosofie, en stellen dat deze niet van toepassing is op de epidemiologie. Deze kritiek is grotendeels onjuist or achterhaald. Alleen epidemiologische hypotheses die verworpen kunnen worden, zijn in staat om bevestigd en bekrachtigd te worden, om te 'corroboreren' zoals Popper dat noemt. En hypotheses kunnen alleen verworpen worden als negatieve resultaten worden meegewogen. Zonder de mogelijkheid van negatieve resultaten, zijn positieve resultaten zonder betekenis.

Dit hoofdstuk eindigt met een overzicht van diverse dissemination biases, oftewel vertekeningen in de rapportage en de verspreiding van onderzoeksgegevens, waarbij positieve resultaten meer aandacht krijgen dan negatieve resultaten. Deze biases zijn schadelijk voor de groei van wetenschappelijke kennis binnen de epidemiologie. Er is al veel onderzocht verricht naar outcome reporting bias en publication bias, en er zijn ook goede oplossingen voorgesteld. Voor citatiebias is dat nog niet het geval.

Hoofdstuk 2 beschrijft een systematische review en meta-analyse over citatiebias. De systematische review laat zien dat er diverse onderzoeksmethodes zijn gebruikt om citatiebias mee te onderzoeken. De methodes variëren in de afbakening van het netwerk (oftewel de methode voor artikelselectie), in de manier waarop studie-uitkomst was gemeten, en welke statistische analyses er waren uitgevoerd. Ondanks al deze methodologische verschillen kan er worden geconcludeerd dat positieve publicaties ongeveer twee keer zo vaak worden geciteerd als negatieve 
citaties. Dit geeft blijk van een bescheiden citatiebias in verschillende onderzoeksvelden. Deze bias is onafhankelijk van de methode voor artikelselectie, maar lijkt groter te zijn als studie-uitkomst wordt gemeten aan de hand van de auteursconclusie in plaats van de daadwerkelijke resultaten.

De dissertatie gaat dan verder met drie citatie-analyses, elk daarvan op een ander epidemiologisch onderwerp. Voor deze citatie-analyses hebben we gekozen voor een claim-specifieke aanpak van artikelselectie. Volgens deze aanpak worden alle relevante artikelen over één specifieke hypothese geselecteerd. Omdat alle artikelen binnen zo'n netwerk over dezelfde hypothese gaan, zou je mogen verwachten dat positieve en negatieve artikelen dezelfde aandacht krijgen, gemeten aan de hand van het aantal keer dat zij geciteerd worden.

Onze eerste citatie-analyse, in Hoofdstuk 3, richt zich op het onderzoek naar de associatie tussen zemmen in chloorwater en de kans op astma bij kinderen. Het lage aantal artikelen in dit netwerk maakte het moeilijk om stevige conclusies te trekken. Er waren desalniettemin wel duidelijke aanwijzingen voor selectieve citatie in dit onderzoeksveld, maar niet voor citatiebias. Interessant was de bevinding dat dit onderzoeksveld werd gedomineerd door twee onderzoeksgroepen. Een van deze groepen produceerde vooral resultaten die de onderzochte hypothese leek te bevestigen, terwijl de andere groep juist een stuk kritischer was.

Hoofdstuk 4 behandelt onze studie naar de hygienehypothese. Deze hypothese was voor het eerst geformuleerd door David Strachan en heeft tot op de dag van vandaag geleid tot een hoop onderzoek over dit onderwerp. De oorspronkeijke versie van deze hypothese stelt dat het gebrek aan infecties in de kindertijd leidt tot een verhoging van het risico op hooikoorts later in het leven. Deze hypothese leidde tot voorspellingen waarvan er een aantal werd verworpen, en dit heeft de aanzet gegeven tot verbetering van de hygienehypothese en verdieping van ons begrip. Ondanks deze kennisontwikkeling leek citatiebias vrij sterk aanwezig te zijn in dit onderzoeksveld.

Tot slot, in Hoofdstuk 5, wordt de wetenschappelijke literatuur naar de associatie tussen dieseluitstoot en longkanker onderzocht. Het laat zien a) dat studieuitkomst en kans op citatie niet gerelateerd lijken te zijn, b) dat studies van hogere kwaliteit vaker geciteerd worden, en c) dat studies die door de transportindustrie zijn gefinancierd veel kritischer zijn over de associatie tussen dieseluitstoot en longkanker dan studies die hun financiering van non-profitorganisaties hebben ontvangen.

Hoofdstuk 6 introduceert een nieuw soort bias: abstract reporting bias. Dit is het fenomeen dat publicaties waarin meerdere associaties zijn onderzocht, alleen die associaties in de abstract rapporteren die positief blijken te zijn. De zoekopdrachten in zoekmachines zoals Web of Science en PubMed zijn echter gelimiteerd tot de titel, abstract en sleutwoorden van een publicatie. Dit heeft als gevolg dat negatieve 
resultaten dus niet zo makkelijk kunnen worden gevonden, zelfs niet als deze resultaten gepubliceerd zijn. Op zijn beurt kan dat dan weer leiden tot een vertekening van systematische reviews, en tot een overschatting van de gepoolde effectgrootte in meta-analyses.

Daarnaast wordt er een methode gepresenteerd waarmee abstract reporting bias geïdentificeerd kan worden, en wordt deze methode toegepast op het onderzoeksveld met betrekking tot de associatie tussen dieseluitstoot en blaaskanker. Het laat zien dat zo'n $20 \%$ van alle gepubliceerde onderzoeksresultaten wordt gemist door de bias in abstract reporting, en dat dit leidt tot een (niet-significante) overschatting van de gepoolde effectgrootte van in totaal zeven procentpunt.

Hoofdstuk 7, tot slot, vergelijkt alle citatie-analyses binnen het Sound Science-project met elkaar. Hieronder vallen ook drie citatie-analyses die niet in deze dissertatie staan maar waarin een vergelijkbare methodologie is gevolgd. Citatiebias was over het algemeen bescheiden aanwezig. Steekproefgrootte, journal impact factor, autoriteit en zelfcitatie bleken sterkere determinanten van citatie te zijn dan dat studie-uitkomst dat is.

Een interessante, exploratieve bevinding is dat citatiebias het sterkst lijkt te zijn in het geval van positieve publicaties. In deze publiaties worden vooral andere positieve publicaties geciteerd, terwijl er in negatieve publicaties geen voorkeur lijkt te zijn om positieve danwel negatieve publicaties te citeren. Onze eerdere bevinding, dat citatiebias het sterkst was als deze is gebaseerd op de auteursconclusie in plaats van de onderliggende resultaten, konden we daarentegen niet repliceren. 